\title{
Peran Pemerintah Desa Terhadap Pembangunan Kewirausahaan Pertanian Sebagai Sarana Untuk Meningkatkan Kesejahteraan Masyarakat
}

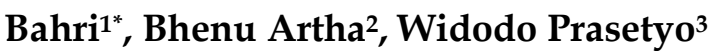 \\ 1,2,3 Prodi Kewirausahaan Fakultas Ekonomi Universitas Widya Mataram \\ *Corresponding author's e-mail: 1bahri@widyamataram.ac.id
}

\begin{abstract}
Abstrak
Peran pemerintah desa dalam membangun kewirausahaan pertanian sangat penting dalam meningkatkan pendapatan dan kesejahteraan masyarakat. Kewirausahaan (entrepreneurship) dibidang pertanian suatu yang sangat penting bagi pengembangan agribisnis. Namun bukti empirisnya pada usaha di sektor on-farm menuju off-farm masih sangat jarang dilakukan. Penelitian ini bertujuan mengetahui peran pemerintah desa terhadap pembangunan kewirausahaan pertanian dan potensi desa dibidang pertanian dan kemampuan masyarakat dalam mengelola hasil pertanian sebagai sarana untuk meningkatkan kesejahteraan, serta untuk mengetahui faktor-faktor pendukung dan kendala-kendalanya. Penelitian ini dilakukan di Desa Gadingharjo Kecamatan Sanden, Kabupaten Bantul, Daerah Istimewa Yogyakarta. Jenis penelitian adalah kualitatif dengan metode survei dan wawancara mendalam (indepth interview). Objek penelitian adalah pemerintah desa (kepala desa, perangkat desa) petani, peternak. Ruang lingkup penelitian ini dibatasi pada peran pemerintah desa terhadap pembangunan kewirausahaan pertanian sebagai sarana untuk meningkatkan kesejahteraan masyarakat, faktor-faktor yang pendukung dan kendalakendala pemerintah desa dalam upaya pembangunan kewirausahaan pertanian masyarakat. Teknik analisis data yang digunakan adalah dari Miles \& Huberman yaitu mulai dari reduksi data, display data dampai pengambilan kesimpulan/varifikasi. Penelitian dilaksanakan pada bulan Februari sampai Mei 2019. Hasil penelitian ialah Pemerintah desa sebagai fasilitator melalui pendampingan dan pemberian fasilitas, Pemerintah desa sebagai mediator, Pemerintah desa sebagai regulator, Pemerintah desa sebagai motivator. Faktorfaktor yang mendukung pemerintah desa dalam upaya pembangunan kewirausahaan pertanian masyarakat adalah sumber daya alam, sumber daya manusia, infrastruktur, ekonomi dan sosial. Sedangkan kendala-kendala pemerintah desa dalam upaya meningkatkan kesejahteraan masyarakat antara lain Kelompok berkepentingan, Kualitas sumber daya manusia pemerintah desa, Program pemerintah tidak berjalan sesuai rencana.
\end{abstract}

\section{Kata Kunci:}

Pemerintah Desa, Kewirausahaan Pertanian, Kesejahteraan Masyarakat

\begin{abstract}
The role of the village government in building agricultural entrepreneurship is very important in increasing the income and welfare of the community. Entrepreneurship in agriculture is very important for agribusiness development. But the empirical evidence on businesses in the on-farm sector towards off-farm is still very rare. Therefore this research is to find out the role of the village government in the development of agricultural entrepreneurship and village potential in agriculture and the ability of the community to manage agricultural products as a means to improve welfare. In addition to knowing the supporting factors and constraints faced by the village government in an effort to improve community welfare. This research was conducted in Gadingharjo Village, Sanden District, Bantul Regency, Special Region of Yogyakarta. This type of research is qualitative research
\end{abstract}


with survey methods and in-depth interviews. The object of this research is the village government (village head, village officials) farmers, farmers. The scope of this research is limited to the role of the village government in the development of agricultural entrepreneurship as a means to improve community welfare, supporting factors and constraints of village government in the efforts to develop community agricultural entrepreneurship. The data analysis technique used in this study is from Miles \& Huberman, starting from data reduction, data display to conclusions/varification. This research was conducted from February to May 2019. The results of the study obtained about the role of the village government in the development of community agricultural entrepreneurship are Village government as facilitator through mentoring and provision of facilities, Village government as mediator, Village government as regulator, Village government as a motivator. The factors that support the village government in developing community agricultural entrepreneurship efforts are Natural resources, Human resources, Infrastructure, Economy and Social. While the constraints of village government in efforts to improve community welfare include Interest groups, Quality of village government human resources, Government programs do not go according to plan.

Keywords:

Village Government, Agricultural Entrepreneurship, Community Welfare

\section{How to Cite:}

Bahri., Bhenu Artha., Widodo Prasetyo. (2019). Peran Pemerintah Desa Terhadap Pembangunan Kewirausahaan Pertanian Sebagai Sarana Untuk Meningkatkan Kesejahteraan Masyarakat Desa Gadingharjo, Sanden, Bantul, Daerah Istimewa Yogyakarta.

Jurnal Penelitian Agrisamudra. 6(2): 82-94

DOI 10.33059/jpas.v6i2.1313

\section{Pendahuluan}

Indonesia tengah memasuki fase transformasi dari negara yang berpendapatan menengah (middle income countries) mejadi negara berpendapatan tinggi (high income countries). Upaya membangun kemampuan ekonomi untuk kemandirian dan daya saing bangsa merupakan bagian dari cita-cita Indonesia untuk sejajar dengan negara lain, oleh karena itu Indonesia perlu menata sistem ekonomi yang berbasis iptek dan inovasi. Pembangunan disegala bidang yang dilakukan pemerintah bertujuan untuk mensejahterakan masyarakat agar tercapai cita-cita masyarakat yang adil dan makmur sehingga dapat mengurangi tingkat kemiskinan dan ketimpangan. Secara nasional, tingkat kemiskinan di perdesaan selalu relatif lebih tinggi dibandingkan dengan tingkat kemiskinan di perkotaan. Tingkat kemiskinan di perkotaan turun dari 11,65\% (2008) menjadi 8,16\% (2014), sedangkan di perdesaan turun dari 18,93\% (2008) menjadi 13,76\% (2014). Dari total rakyat miskin di Indonesia, sekitar $66 \%$ berada di perdesaan dan sekitar 56\% menggantungkan hidupnya dari sektor pertanian (Akhmadi dkk, 2016).

Francis dan David (2012) menjelaskan cara terbaik untuk memberdayakan penduduk perdesaan adalah dengan memberdayakan mereka melalui pekerjaannya. Pertanian merupakan pekerjaan penduduk desa dan pengembangan produksi pertanian dilakukan dengan peningkatan produktivitas antara lain dengan memberikan insentif bagi penyuluh agar mereka melakukan pekerjaannya secara efektif. Perlu 
dilakukan pengkajian program-program pemerintah desa dalam penanggulangan kemiskinan. Sedangkan Menteri Riset Teknologi dan Perguruan Tinggi (Menristekdikti) Mohamad Nasir mengatakan bahwa potensi ekonomi dan inovasi yang ada di daerah merupakan hal penting untuk dikembangkan. Strategi pembangunan di daerah harus difokuskan kepada pengembangan potensi bisnis yang berbasis pada Produk Unggulan Daerah (PUD) antara lain komoditas pertanian, perkebunan, kehutanan, hortikultura hingga industri kreatif (https://ristekdikti.go.id). Menurut Undang-Undang Nomor 6 Tahun 2014 tentang desa membuat kebijakan tentang desa dalam memberi pelayanan, peningkatan peran serta dan pemberdayaan masyarakat desa yang ditujukan bagi kesejahteraan masyarakat. Konsep yang sering dimunculkan dalam proses pemberdayaan adalah konsep kemandirian dimana program-program pembangunan dirancang secara sistematis agar individu maupun masyarakat menjadi subjek dari pembangunan. Dalam Peraturan Pemerintah Republik Indonesia Nomor 39 Tahun 2012 tentang penyelenggaraan kesejahteraan sosial dijelaskan dalam pasal 1 bahwa penyelenggaraan kesejahteraan sosial merupakan upaya yang terarah, terpadu, dan berkelanjutan yang dilakukan pemerintah dalam memenuhi kebutuhan dasar setiap warga negara, yang meliputi rehabilitasi sosial, jaminan sosial, pemberdayaan sosial, dan perlindungan sosial, dan kesejahteraan sosial.

Kewirausahaan efektif dapat meningkatkan kesejahteraan masyarakat melalui kontribusinya pada peningkatan pertumbuhan ekonomi. Negara yang memiliki masyarakat giat berwirausaha mampu menggerakkan roda perekonomian yang meningkatkan kesejahteraan masyarakatnya. Program Agroindustri dibidang kewirausahaan dapat menjadi harapan dan jalan untuk mensejahterakan masyarakat pertani selama pembangunan subsektor perekonomian ini selalu dibangun bersama petani atau masyarakat perdesaan dimana petani di bimbing untuk melakukan pengelolaan dari hasil pertaniannya untuk bisa mempunyai harga jual tinggi.

Menurut Lakitan (2011a) kegiatan pengelolaan lahan produksi pertanian sering disebut sebagai kegiatan on-farm sedangkan kegiatan subsistem agribisnis yang lainnya seperti pengelolaan hasil pertanian agar mempunyai jual tinggi disebut sebagai kegiatan-kegiatan off -farm. Sedangkan Kim et al. (2010) dalam Lakitan (2011b) menyatakan bahwa pertumbuhan perekonomian berbasis pertanian yang dilakukan oleh petani akan terus menurun dan akan segera mencapai batasnya, tentunya jika tidak dilakukan terobosan-terobosan baru dalam pembangunan pertanian

Potensi dusun Gadingharjo dalam pengembangan wirausahaon farm dan off farm sangat bagus. Dusun Gadingharjo yang lokasinya tidak jauh dari pantai, merupakan wilayah yang berpotensi untuk kegiatan usaha/perdagangan. Lokasi dusun yang dilalui jalan Parangtritis sangat berpotensi untuk usaha, apalagi saat liburan atau hari raya tiba. Potensi wirausaha hasil pertanian atau perkebunan di Dusun Gadingharjo sangat bagus untuk dikembangkan. Sebagian banyak warga Gadingharjo yang memiliki tanah pertanian atau perkebunan. Akan tetapi yang menjadi permasalahan saat ini, Warga yang memiliki tanah disepanjang jalan sudah dibangun ruko/los. 
Dimana yang membangun bukan dari kalangan warga setempat melainkan dari daerah lain bahkan dari luar kabupaten Bantul. Tidak hanya itu saja ada beberapa petani masih menjual hasil pertaniannya langsung pengepul (penebas). Warga menjual hasil panenan seperti padi, palawija dan juga bawang merah. Mata pencaharian warga selain bertani, juga beternak sapi, kambing.

Fenomena lain menunjukkan bahwa sentra industri-industri besar tidak ada di dusun Gadingharjo. Kondisi saat ini yag ada hanya usaha kecil yang bersifat rumahan, yaitu pedagang makanan kecil seperti jajan pasar, emping belinjo yang dijual di pasar maupun dijual di lokasi wisata pantai Parangtritis. Keahlian warga dusun Gadingharjo terbatas pada kemampuan usaha perdagangan kecil-kecilan dan belum dapat mengembangkan potensi yang ada. Potensi yang dapat dikembangkan sebagai daerah yang lokasinya dekat dengan obyek wisata pantai. Keahlian warga dusun Gadingharjo sebatas sebagai petani, buruh degan penghasilan harian, sopir, kernet, laden tukang dan usaha berjualan makanan kecil/ jajan pasar. Sebagian kecil usaha toko kelontong dan buruh tani. Hanya mereka yang memiliki modal usaha sebagai pengepul hasil panenan apabila musim panen tiba.

Berdasarkan fenoma ini pengembangan komoditas kelompok tani, peternak dan usaha masyarakat Gadingharjo sangat membutuhkan peran dari pemerintah desa. Pemerintah desa terdiri dari Kepala Desa dan Perangkat Desa. Perangkat Desa terdiri dari Sekretaris Desa (Sekdes) dan Perangkat Desa lainnya. Tanpa dukungan dan keputusan-keputusan yang tepat dari pemerintahan desa maka kewirausahaan pertanian desa akan sulit dibangun.Peran pemerintah desa dalam menerapkankan program-program desa, mengembangkan bakat masyarakat, memberikan pelatihan untuk meningkatkan keterampilan anggota masyarakat dalam bidang wirausaha sangat dibutuhkan dan membantu membangun sentral industri usaha yang lebih besar.

Potensi Desa Gadingharjo untuk pengembangan sektor industri bisnis dibidang pertanian, peternakan dan perkebunan pemerintah sangat membutuhkan dukungan masyarakat. Hal ini terbukti dalam perencanaan pembangunan di sektor pertanian didasarkan pada tata ruang dan ketersediaan lahan. Namun dalam meningkatkan kesejahteraan masyarakatnya melalui program pemerintah desa Gadingharjo masih ada masalah dan kendala-kendala yang dihadapi.

\section{Metode Penelitian}

Jenis penelitian ini adalah penelitian kualitatif dengan wawancara mendalam (indepth interview). Penelitian ini menggunakan teknik analisis mendalam (in-depth analysis), yaitu mengkaji masalah secara kasus perkasus karena metodologi kulitatif yakin bahwa sifat suatu masalah satu akan berbeda dengan sifat dari masalah lainnya. Menurut Sugiyono (2015) metode penelitian kualitatif merupakan metode penelitian yang berlandaskan pada filsafat positivisme, digunakan untuk meneliti pada kondisi obyek yang alamiah.Teknik pengumpulan data dilakukan dengan mengunakan metode observasi, wawancara, dokumentasi. Metode analisis data menggunakan reduksi data, penyajian data, penarikan kesimpulan. Objek penelitian ini Kepala Desa 
1 orang, Pamong Desa 6 orang, Kepala Pedukuhan 6 orang, Masyarakat Petani sebanyak 6 orang, maka total sampel sebanyak 19 orang. Metode pengambilan sampel dilakukan secara sengaja (Purposive Sampling) dengan pertimbangan bahwa Desa Gadingharjo merupakan salah satu desa di Kabupaten Bantul yang sebagian besar penduduknya berprofesi sebagai petani, peternak. Ruang lingkup penelitian ini berkaitan tentang peran pemerintah desa terhadap pembangunan kewirausahaan pertanian sebagai sarana untuk meningkatkan kesejahteraan masyarakat Desa Gadingharjo, Kec. Sanden, Kab. Bantul, Daerah Istimewa Yogyakarta. Faktor-faktor pendukung dan kendala pemerintah desa dalam upaya pembangunan kewirausahaan pertanian masyarakat Desa Gadingharjo, Kec. Sanden, Kab. Bantul, Daerah Istimewa Yogyakarta. Waktu penelitian dilakukan pada bulan Februari sampai Mei 2019.

\section{Hasil dan Pembahasan}

\section{Deskripsi Letak dan Luas Desa Gadingharjo}

Desa Gadingharjo adalah desa yang berada di Kabupaten Bantul, Kecamatan Sanden. Desa yang memiliki arti pada namanya, Gading yaitu Taring Gajah, Harjo yaitu Makmur/Subur. Desa ini termasuk desa yang kaya akan sumber alamnya, dari tanaman, hewan ternak. Desa yang berada diwilayah bantul ini memiliki luas wilayah 308.93 Ha. Banyak Potensi yang di miliki oleh Desa ini dari Potensi Pertanian, Peternakan, Perkebunan, Perikanan, Industri, dan Wisata. Desa Gadingharjo secara astronomis terletak di 7.979354, LS sampai 800'11" LS dan 110.263966 BT sampai 110016"08" BT. Secara administratif terdiri dari 6 pedukuhan yaitu Kalimundu, Daleman, Merten, Ngunjung, Pranti, Karanganyar.

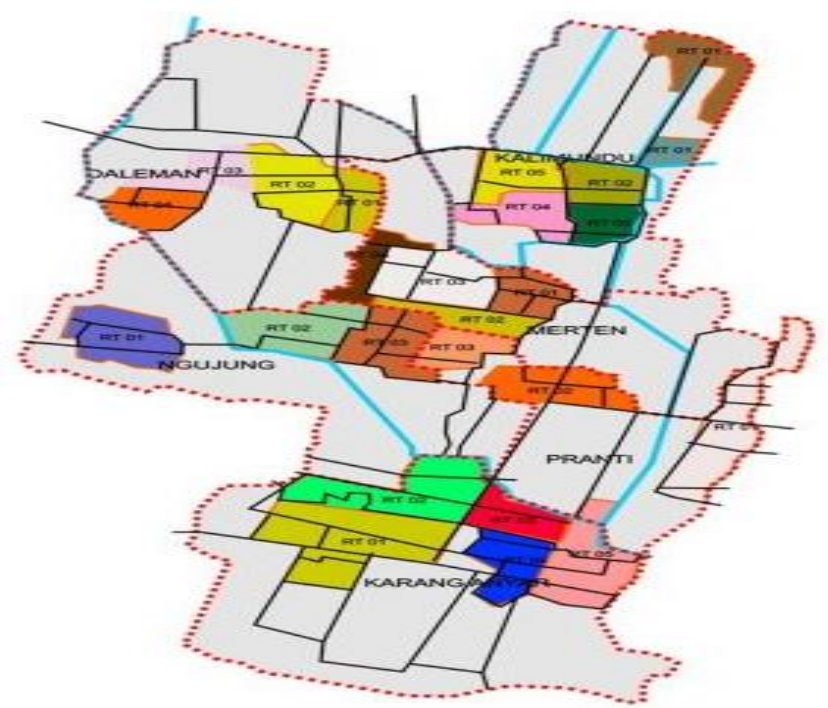

Gambar 1. Peta Pembagian Wilayah Administratif Desa Gadingharjo 
a. Profil Kependudukan Desa Gadingharjo

1). Data Kependudukan Berdasarkan Jenis Kelamin

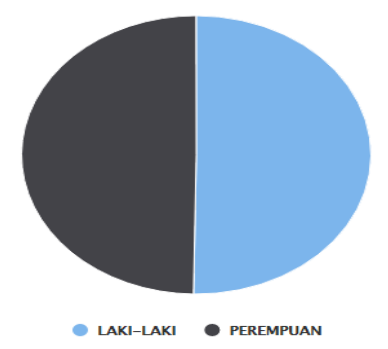

\begin{tabular}{ll} 
Jenis Kelamin & Jumlah \\
\hline LAKI-LAKI & 1944 \\
\hline PEREMPUAN & 1924 \\
\hline Total & $\mathbf{3 8 6 8}$
\end{tabular}

Gambar 2. Data Kependudukan Berdasarkan Jenis Kelamin

2). Data Pendidikan dan Pekerjaan Desa Gadingharjo

a. Data Pendidikan

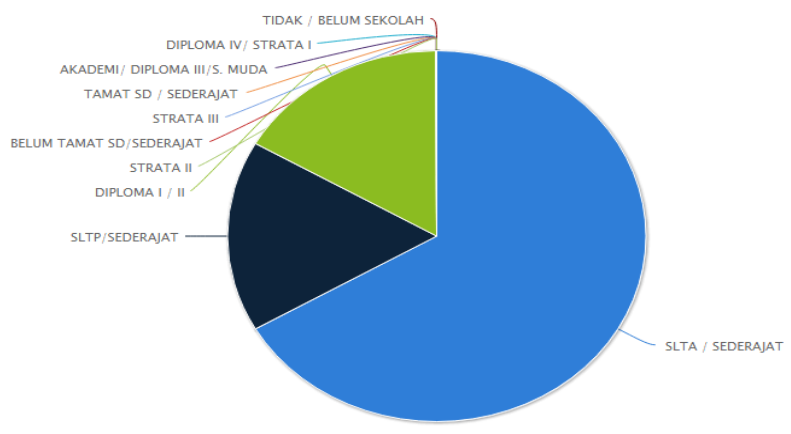

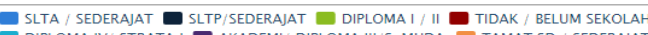

Belum TAMAT SD/SEDERAJat DTRATA

Gambar 3. Statistik Berdasarkan Pendidikan

b. Data Pekerjaan

Chart title

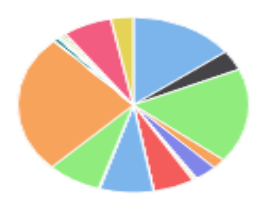

BELUM/TIDAK BEKERJA

- MENGURUS RUMAH TANGGA

PELAJAR/MAHASISWA

PENSIUNAN

TENTARA NASIONAL INDONESIA

KEPOLISIAN RI

PETANI/PEKEBUN

- kARYAWAN SWASTA

BURUH HARIAN LEPAS

TUKANG BATU

DOSEN

- PERDAGANGan

- NELAYAN/PERIKANAN

- KARYAWAN HONORER

BURUH TANI/PERKEBUNAN

TUKANG KAYU

Gambar 4. Statistik Berdasarkan Pekerjaan 
Dari data chart diagram diatas menunjukkan bahwa masyarakat yang bekerja disektor pertanian sebesar 5,7\%, sebagai buruh tani/perkebunan sebesar 25,5\%, masyarakat yang memilih menjadi wiraswasta 6,9\%, dari total jumlah penduduk sebanyak Gadingharjo 2.064. Sedangkan berdasarkan tabel 2 masyarakat yang menjadi petani, kebun sebanyak 222 dan buruh tani/perkebunan 987 orang. Maka data ini tingkat pertanian, perkebunan di desa Gadingharjo masih tinggi apalagi yang menjadi buruh pertanian dan perkebunan.

\section{Peran Pemerintah Desa Terhadap Pembangunan Kewirausahaan Pertanian Masyarakat di Desa Gadingharjo}

Pemerintah desa memegang peranan yang sangat penting dalam menciptakan tata pemerintahan yang baik dan mendorong pemberdayaan masyarakat serta memberikan pelayanan pada masyarakat dalam pembentukan program - program yang dijalankan. Salah satu program yang dibentuk oleh pemerintah desa adalah pemberdayaan petani untuk meningkatkan hasil pertanian dan penjualan. Untuk meningkatkan hasil pertanian dan penjualan maka perlunya ada pengolahan dan pemberian nilai tambah (value added) pada barang yang akan dijual ke pembeli.Nilai tambah (value added) merupakan pertambahan nilai suatu komoditas karena mengalami proses pengolahan, pengangkutan ataupun penyimpanan dalam suatu produksi (Hamidah dkk, 2015). Dalam proses pengolahan, nilai tambah merupakan selisih antara nilai produk dengan biaya-biaya yang dikeluarkan seperti biaya bahan baku dan input lainnya, tidak termasuk tenaga kerja (Hayami et.al,1987). Awaludi (2014) dalam (Kusumawati, 2016) dijelaskan sumber nilai tambah terbesar bagi produk pertanian adalah pada pengolahan dan kegiatan penjualan/pemasaran (Awaludin, 2014).

Peningkatan kesejahteraan masyarakat petani melalui program pemerintah desa sangat diperlukan demi mengontrol jalannya tata penyelenggaraan pemerintahan desa yang lebih baik (Good Local Governance). Pemerintah desa berperan dalam memandirikan dan mensejahterahkan masyarakat khususnya petani melalui suatu usaha yakni usaha pertanian di bidang agribisnis. Dalam penelitian ini peneliti mengkaji lebih dalam mengenai peran pemerintah desa terhadap pembangunan kewirausahaan pertanian melalui program-program pemerintah desa. Adapun peran pemerintah desa terdapat dalam bagan dibawah ini:

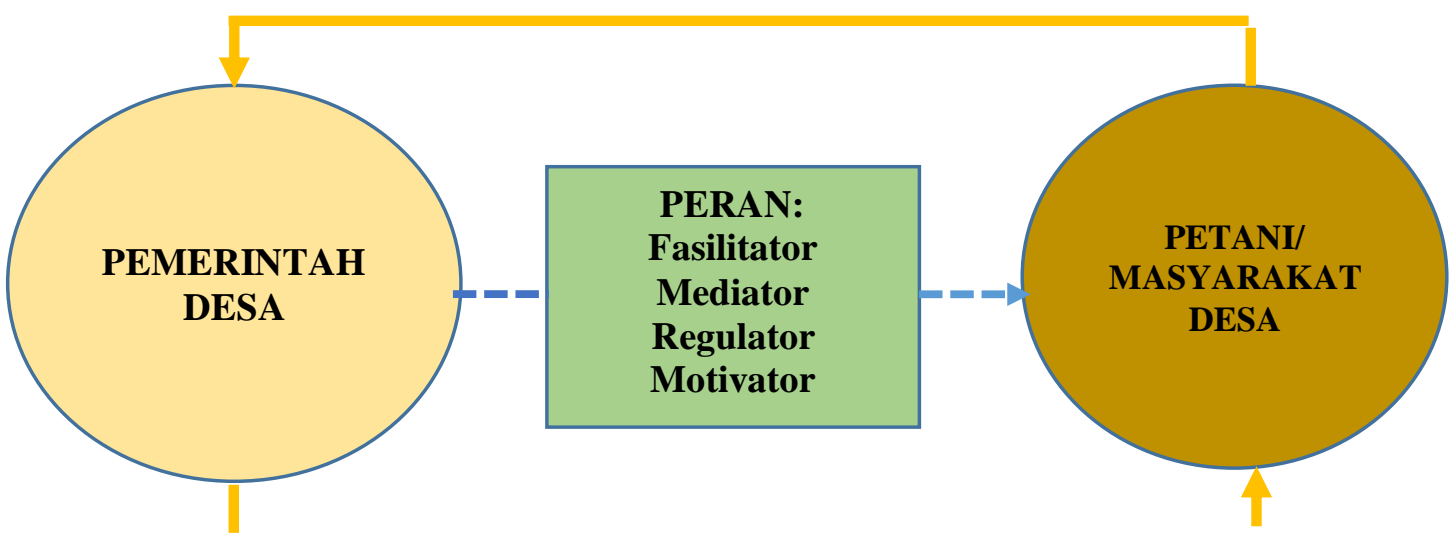


Gambar 5. Peran Pemerintah Desa Untuk Meningkatkan Kesejahteraan

\section{Pemerintah Desa Sebagai Fasilitator (Dukungan)}

Peran pemerintah desa Gadingharjo dalam hal ini kepala desa memberikan dorongan agar ide-ide bisnis masyarakat Gadingharjo lebih baik dan mempunyai nilai jual tinggi. Berdasarkan hasil penelitian diketahui bahwa pemerintah desa melakukan pendampingan dan memberikan fasilitas.

(1). Pendampingan
(a). Pendampingan kepengurusan perijinan PIRT (Pangan Industri Rumah Tangga)
(b). Pendampingan pelatihan pembuatan inovasi produk stik ubi ungu
(c). Pendampingan pelatihan pembuatan tepung ubi ungu
(d). Pendampingan pelatihan penanaman sayur hidropolik
(e). Pendampingan pendirian koperasi petani
(f). Pendampingan pembentukan kelompok tani

(2). Memfasilitasi
(a). Memfasilitasi akses terhadap pinjaman modal dari bank, akses pakan ternak, akses pasar, pelatihan cara pertanian hidropolik
(b). Memfasilitasi adanya penyuluhan tentang manajemen usaha dan pemasaran
(c). Memfasilitasi pemberian alat bajak sawah (traktor)
(d). Memfasilitasi penggunaan teknologi pertanian modern seperti: penggunaan benih unggul, penggunaan pupuk organik, tanaman benih muda kurang 15
(e). Membantu perbaikan dan perluasan irigasi
(f). Memfasilitasi dalam membangun hubungan kemitraan usaha

\section{Pemerintah Desa Sebagai Mediator (Mediasi)}

Berdasarkan hasil penelitian diketahui bahwa Kepala Desa Gadingharjo bertindak sebagai mediator antara petani dengan pembeli. Kepala desa Gadingharjo memediasi antara pembeli dan masyarakat untuk membeli hasil pertanian, perkebunan dan perternakan yang sudah diolah menjadi produk untuk dibeli dengan harga jual yang pantas. Tujuan dari kegiatan ini untuk meningkatkan pendapatan masyarakat Gadingharjo. Tetapi masih ada juga petani yang menjual hasil panennya langsung ke pengepul. Selain itu Kepala Desa Gadingharjo juga mengimbau masyarakatnya untuk membeli pupuk di toko-toko dalam pedukuhan Desa Gadingharjo. Selain itu Kepala Desa Gadingharjo dalam menyelesaikan masalah atau konflik yang terjadi yaitu diselesaikan melalui musyawarah, yang menguntungkan kedua belah pihak dan tidak ada yang dirugikan.

\section{Pemerintah Desa Sebagai Regulator}

Berdasarkan hasil penelitian peran Pemerintah Desa Gadingharjo memberikan kemudahan masyarakat dalam mengurus persyaratan administratif kepada setiap masyarakatnya seperti kemudahan kepengurusan perizinan pendirian usaha baik dari sisi administrasi maupun waktu kepengurusan dan tidak memberlakukan pajak usaha di desa.

\section{Pemerintah Desa Sebagai Motivator}


Berdasarkan hasil penelitian Kepala Desa Gadingharjo memotivasi masyarakat melalui bimbingan secara langsung pada petani. mengundang akademisi untuk penyuluhan, Kunjungan dinas pertanian, kepala desa juga mengundang Dosen-Dosen, Penulis, program Bedah Buku dengan tema "Jiwa Kewirausahaan, Para Pelaku Bisnis (Wirausahawan). Dengan adanya kegiatan-kegiatan tersebut akan tercipta sikap semangat berwirausaha.

Hasil penelitian di atas dibuktikan dengan hasil penelitian dariSony Kristanto (2013) tentang "Peran Pemerintah Desa dalam Meningkatkan Pemberdayaan Masyarakat di Desa Lidung Kemenci Kecamatan Mentarang Kabupaten Malinau". Hasil penelitiannya adalah peran kepala desa cukup baik. Peran yang dilakukan dengan menampung dan menyalurkan aspirasi masyarakat, penyusunan kegiatan pembangunan secara partisipatif, berswadaya dan gontong royong serta menggali potensi sumber daya yang ada untuk kepentingan pembangunan di desa.

Sedangkan penelitian Surya Effendi (2008) tentang "Upaya Pemerintah Desa dalam Meningkatkan Kesejahteraan Masyarakat di Desa Taman Rahayu Kecamatan Setu Kabupaten Bekasi." Hasil penelitian didapatkan ada dua upaya pemerintah yaitu (1) melalui pelatihan dan penyuluhan ibu-ibu PKK, (2) penyuluhan dan peningkatan masyarakat yang berprofesi sebagai pengrajin di industri assesoris.

Faktor-Faktor yang Mendukung Pemerintah Desa Dalam Upaya Pembangunan Kewirausahaan Pertanian Masyarakat Desa Gadingharjo

\section{a. Sumber Daya Alam}
(1). Kepemilikan lahan pertanian dan perkebunan masih sangat luas
(2). Karakteristik lahan pertanian dan perkebunan yang subur
(3). Ketersediaan pakan ternak (padang rumput) luas
(4). Tersedianya hewan (sapi, kambing) yang sehat
(5). Kondisi iklim/cuaca

b. Sumber Daya Manusia
(1). Kekuasaan
(2). Pendidikan formal dan informal yang maju
(3). Sistem terbuka pada lapisan masyarakat
(4). Adanya orientasi masyarakat untuk maju (masa depan)
(5). Adanya pengetahuan/keterampilan masyarakat dalam mengolah hasil pertanian menjadi produk siap jual
(6). Adanya pelatihan agar konsisten dalam menjaga kualitas produk

\section{c. Infrastruktur}

(1). Kondisi infrastruktur: kondisi jalan raya sudah memadai (aspal) dan sudah dilakukannya perluasan dan penggaliam saluran irigasi

(2). Tersedianya alat-alat produksi pupuk organik

(3). Tersedianya pasar tradisional ditingkat desa/dusun

\section{d. Ekonomi}

(1). Adanya akses peminjaman modal di Bank

(2). Ketersediaan kesempatan kerja di bidang pertanian 
(3). Kepemilikan lahan menjadi modal awal dalam berwirausaha

e. Sosial

(1). Adanya sinergitas yang baik antara pemerintah dan masyarakat (praktik kegotongroyongan masih kuat)

(2). Adanya kemauan berkelompok masyarakat dalam membentuk koperasi

(3). Daya beli kebutuhan masyarakat masih tinggi.

\section{Kendala-Kendala Pemerintah Desa Dalam Upaya Meningkatkan Kesejahteraan Masyarakat Desa Gadingharjo}

Menurut hasil wawancara dengan kepala desa Gadingharjo bapak Aan Indra Nursanta S.S menyatakan bahwa mayoritas penduduknya bermata pencaharian petani dan peternak yang menghasilkan beberapa program bantuan kegiatan di bidang pertanian dan perternakan. Akan tetapi masih ada kendala-kendala yang menjadi penghambat program pemerintah. Kendala yang muncul antara lain:

\section{a. Kelompok Berkepentingan}

Kelompok kepentingan dapat menjadi salah satu penghambat dalam upaya peningkatan kesejahteraan msyarakat. Misalnya,upaya pemberdayaan petani di desa Gadingharjo tidak dapat dilaksanakan karena ada kelompok berkepentingan tertentu membeli lahan pertanian untuk mendirikan ruko atau perumahan.

b. Kualitas Sumber Daya Manusia Pemerintah Desa

Sumber daya manusia atau aparat yang bertugas pada organisasi kantor tersebut secara kuantitas jumlah pegawai yang ada pada kantor desa Gadingharjo sudah cukup namun secara kualitas sumber daya aparat desa di desa Gadingharjo belum cukup baik, hal ini dapat dilihat dari kemampuan kerja dan mengkoordinir program didesa yang masih terlihat belum berjajalan. Dalam pengembangan dan pendampingan program bantuan masih muncul kendala-kendalanya.

c. Program Pemerintah Tidak Berjalan Sesuai Rencana

Adapun bentuk program-program bantuan dan kendalanya antara lain:

(1). Pengolahan Emping Mlinjo

Desa Gadingharjo salah satu desa penghasil belinjo tepatnya di dusun Daleman. Namun belum bisa diolah secara baik dan modern. Penyebabnya pengolahan emping mlinjo masih sederhana dengan cara belinjo direbus bisa dan ditumbuk. Kendalanya masyarakat belum memiliki alat teknologi terbaru yang memudahkan, cepat dan praktis dalam bekerja.

(2). Pengolahan Biogas

Di Desa Gadingharjo sudah digalakkan pengolahan Biogas tepatnya di dusun Karanganyar sudah terdapat penampung bantuan dari Pemda Kab. Bantul. Akan tetapi kendalanya sampai saat ini masyarakat belum bisa memanfaatkan bantuan tersebut karena belum bisa mengolahnya dan belum merata keberadaanya. Padahal kepemilikan hewan ternak di dusun ini sangat banyak yang kotorannya bisa diolah menjadi biogas.

(3). Pengolahan Kotoran Ternak Menjadi Pupuk 
Dengan banyaknya peternak kambing, sapi, maupun hewan lain di pedukuhan Desa Gadingharjo maka biasanya petani langsung mengunakan pupuk kandang ke sawah tanpa pengolahan lebih lanjut. Sehingga kendalanya adalah masih banyak sekali hama dan rumput yang terbawa. Untuk itu bapak kepala desa memohon untuk masyarakatnya ada akademisi atau stakeholder memberi bimbingan berkaitan dengan cara memodifikasi pupuk kandang dengan teknologi modern.

(4). Pemanfaatan Urine Hewan Dijadikan Pupuk Organik

Urine biasanya tidak di manfaatkan untuk apapun ataupun dibuang begitu saja tanpa di tambah nilai gunanya. Di ketiga dusun yaitu Dusun Daleman, Merten dan Karangnayar banyak sekali peternak sapi, kambing, kelinci yang dibuang begitu saja urine. Kendalanya belum ada penelitian dan pembimbingan pada masyarakat untuk mengubah urine hewan tersebut menjadi pupuk tanaman atau peyemprot hama tanaman.

(5). Pencacah Sayuran Sebagai Bahan Campuran Pakan Ternak

Desa Gadingharjo di 6 pedukuhan rata-rata. menjadi peternak lele, bebek, kambing dan sapi. Sebagai bahan makanan tambahan biasanya peternak membuatkan jenang yang bahan dasarnya terbuat dari sayur yang tidak terpakai dan bonggol pisang. Untuk perajangannya membutuhkan waktu 1 sampai 2 jam untuk sekali pembuatan pakan. Kendalanya perajangan pakan tadi masih menggunakan alat manual seperti parang belum menggunakan mesin sehingga membutuhkan waktu lama. Bapak kepala desa berharap ada bantuan atau dibuatkan alat untuk membantu merajang sayuran dan bonggol pisang agar lebih memudahkan pembuatan pakan dan efisiensi waktu peternak dalam pembuatan pakan.

(6). Alat Pemotong Padi dan Perontok Padi

Pada saat pemanenan padi biasanya masyarakat masih melakukanya menggunakan alat sederhana, menyebabkan proses pemanenan menjadi lama. Kendalanya masyarakat belum memiliki mesin pemanen padi terbaru. Berharap ada alat yang terbarukan yang dapat memudahkan petani memanen.

\section{Simpulan}

Berdasarkan pembahasan diatas maka diambil kesimpulan dalam penelitian ini sebagai berikut peran Pemerintah Desa Terhadap Pembangunan Kewirausahaan Pertanian Masyarakat Desa Gadingharjo adalah sebagai fasilitator, mediator, regulator dan modifikator, faktor-Faktor yang Mendukung Pemerintah Desa Dalam Upaya Pembangunan Kewirausahaan Pertanian Masyarakat Desa Gadingharjo adalah Sumber Daya Alam. Sumber Daya Manusia, Infrastruktur, Ekonomi dan Sosial, kendala-Kendala Pemerintah Desa Dalam Upaya Meningkatkan Kesejahteraan Masyarakat Desa Gadingharjo adalah Kelompok Berkepentingan, Kualitas Sumber Daya Manusia Pemerintah Desa serta Program Pemerintah Tidak Berjalan Sesuai 
Rencana. Oleh karena itu diharapkan pemerintah desa selalu membuat programprogram, selalu memberikan pelatihan wirausaha, pendampingan pembentukan kelompok tani, memberikan fasilitas yang mendukung masyarakat dan berwirausaha, serta selalu memberikan kemudahan dalam administrasi, membuka akses masyarakat dalam bantuan permodalan, membantu dalam mencarikan pembeli produk-produk masyarakatnya.

\section{Daftar Pustaka}

Akhmadi. Siregar, Hermanto.\&Hutagaol, M Parulian.Pengembangan Agribisnis Sebagai Strategi Penanggulangan Kemiskinan di Perdesaan. Jurnal Manajemen E Agribisnis, Vol. 13 No. 3, November 2016, hal. 240-253.

Effendi, Surya. 2008. Upaya Pemerintah Desa dalam Meningkatkan Kesejahteraan Masyarakat di Desa Taman Rahayu Kecamatan Setu Kabupaten Bekasi. Skripsi, Jakarta: Universitas Islam Negeri Syarif Hidayatullah.

Hamidah,Mutmaini., Yusra., Abdul Hamid A., \&Sudrajat, Jajat. Analisis Nilai Tambah Agroindustri Kripik Ubi di Kota Pontianak. Jurnal Social Economic of Agriculture, Vol.4, No.2, Desember 2015, hal. 60-73.

Hayami Y, Kawagoe T, Morooka Y, Siregar M. 1987. Agricultural Marketing andProcessing in Upland Java. A Perspective from a Sunda Village. Bogor: TheCPGRT Centre.

Kristanto, Sony. Peran Pemerintah Desa Dalam Meningkatkan Pemberdayaan Masyarakat di Desa Lidung Kemenci Kecamatan Mentarang Kabupaten Malinau". Jurnal Ilmu Pemerintahan, Vol 1, No. 1, Desember 2013, hal. 28-47.

Kusumawati, Rita. Pendampingan Pengolahan Ubi Ungu Berbasis Value Added Method. JurnalBERDIKARI, Vol.4 No.2, Agustus 2016, hal. 73-83.

Lakitan, Benyamin. 2011a. Membangun Agroindustri dan Mewujudkan Sistem Inovasi: agar teknologi berkontribusi pada kesejahteraan rakyat. Keynote Speech pada Seminar dan Lokakarya Nasional Pengembangan Agroindustri Kalimantan Selatan. Fakultas Pertanian Universitas Lambung Mangkurat, Banjarbaru, 23 Juni 2011.

Lakitan, Benyamin. 2011b. National Innovation System in Indonesia: present status and challenges. Paper presented at the Annual Meeting of Science and Technology Studies, GRIPS-Tokyo, 10-12 June 2011.

Sarjono, Joni Joko,dkk. 2014. Peranan Pemerintah Dalarn Pemberdayaan Pedagang Kaki Lima di Kecarnatan Pontianak Tirnur. Jurnal Tesis PMIS. UNTAN PSS 2014. Pontianak: Universitas Tanjungpura.

Saputra, AriDian., \& Susena. Kontribusi Mata Kuliah Kewirausahaan dalam Menumbuhkan Jiwa Entrepreneurship yang Beretika pada Mahasiswa Prodi PPKN FKIP UAD Yogyakarta. Jurnal Citizenship, Vol. 2, No. 1, Juli 2013, hal. 41-48.

Siagian, Sondang., P.2008. Manajemen Sumber Daya Manusia. EdisiPertama. Jakarta: Binapura Aksara.

Sugiyono. 2015. Metode Penelitian Kombinasi (Mix Methods). Bandung: Alfabeta.

Soekanto, Soerjono.2004 Sosiologi SuatuPengantar. Jakarta: Raja GrafindoPersada.

Suryana. 2009. Kewirausahaan (Pedoman Praktis: Kiat dan Proses Menuju Sukses. Jakarta: Salemba Empat. 
Undang-Undang Republik Indonesia Nomor 6 Tahun 2014 Tentang Desa Peraturan Pemerintah Republik Indonesia Nomor 39 Tahun 2012 tentang penyelenggaraan kesejahteraan sosial.

https://ristekdikti.go.id/kabar/menristekdikti-inovasi-harus-mampu-meningkatkankesejahteraan-masyarakat. Diakses tanggal 20 April 2018.

https://gadingharjo.bantulkab.go.id/index.php/first/artikel/33. Diakses 20 April 2019.

https://gadingharjo.bantulkab.go.id/index.php/first/penduduk/pekerjaan. Diakses 20 April 2019.

https://gadingharjo.bantulkab.go.id/index.php/first/statistik/pendidikan-dalam-kk. Diakses 20 April 2019. 